\title{
Aktivitas Superoxide Dismutase pada Serum Darah Babi Landrace yang Disembelih dengan Metode Electrical Stunning
}

\author{
(THE ACTIVITY OF THE SUPEROXIDE DISMUTASE ENZYME IN THE BLOOD SERUMS \\ OF LANDRACE PIG SLAUGHTERED BY THE ELECTRICAL STUNNING METHOD)
}

\author{
Shabrina Fauzia Prayoga ${ }^{1}$, Kuncoro Puguh Santoso ${ }^{2}$, \\ Nove Hidajati ${ }^{2}$, Faisal Fikri ${ }^{2}$, Maya Nurwartanti Yunita ${ }^{3}$, \\ Muhammad Thohawi Elziyad Purnama ${ }^{1, *}$ \\ ${ }^{1}$ Departemen Anatomi Veteriner, \\ ${ }^{2}$ Departemen Ilmu Kedokteran Dasar Veteriner, \\ ${ }^{3}$ Departemen Patologi Veteriner, \\ Fakultas Kedokteran Hewan, Universitas Airlangga \\ Kampus C Unair, Jl. Mulyorejo, Surabaya 60115, Indonesia \\ *Email: thohawi@fkh.unair.ac.id
}

\begin{abstract}
ABSTRAK
Tujuan penelitian ini untuk menentukan aktivitas Superoxide Dismutase (SOD) pada babi Landrace yang disembelih dengan metode stunning dan non-stunning. Sebanyak 18 ekor babi Landrace jantan dewasa yang telah dikebiri dengan masing-masing bobot $115 \pm 20 \mathrm{~kg}$ dibagi menjadi dua kelompok, yakni stunning dan non-stunning dengan pengujian serum pada pre dan post treatment. Electrical stunning dilakukan dengan aliran listrik pada dua elektroda sebesar 220 volt dan 1,3 ampere. Sampel darah diambil sebanyak $3 \mathrm{~mL}$, kemudian diuji aktivitas SODnya.. Hasil aktivitas SOD dianalisis dengan uji T berpasangan untuk membandingkan aktivitas SOD serum antara stunning dan non-stunning pada fase pre dan post treatment. Hasil stunning menunjukkan penurunan signifikan $(p<0,05)$ aktivitas SOD sebesar

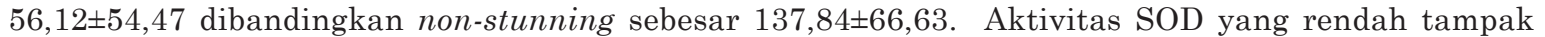
signifikan $(\mathrm{p}<0,05)$ juga pada pre-treatment dibandingkan dengan post-treatment. Dapat disimpulkan bahwa penyembelihan dengan metode electrical stunning menurunankan aktivitas SOD pada serum babi Landrace.
\end{abstract}

Kata-kata kunci: superoxide dismutase; stunning; babi Landrace

\begin{abstract}
This study aimed to determine the activity of the enzyme Superoxide Dismutase (SOD) in Landrace pigs that were slaughtered using stunning and non-stunning methods. A total of 18 adult male Landrace pigs that had been castrated, weighing $115 \pm 20 \mathrm{~kg}$ were divided into two groups, i.e. stunning and nonstunning with serum testing at pre and post treatment, respectively. Electrical stunning was done by electric current on two electrodes of 220 Volts and 1.3 Amperes. A $3 \mathrm{ml}$ blood sample was taken, then SOD activity was tested with the StressXpress ${ }^{\circledR}$. The SOD activity were analyzed using T paired test to compare serum SOD activity between stunning and non-stunning in the pre and post treatment phases. The stunning results showed a significantly decreased $(\mathrm{p}<0.05)$ of SOD activity $(56.12 \pm 54.47)$ compared to non-stunning (137.84 \pm 66.63$)$. Meanwhile, low SOD activity was significant $(\mathrm{p}<0.05)$ also in pre-treatment compared to post-treatment. It can be concluded that slaughtering with electrical stunning alleviated significantly in the SOD activity of Landrace pig serum.
\end{abstract}

Keywords: superoxide dismutase; stunning; Landrace pig 


\section{PENDAHULUAN}

Penyembelihan merupakan tindakan untuk menghilangkan nyawa hewan menggunakan benda tajam dengan syarat terpotong trachea, esophagus, vena jugularis dan arteri carotis communis. Menurut Goba (2013) dan Dannar et al. (2015) penyembelihan pada babi dilakukan dengan cara menusuk bagian leher ke arah anterior sternum yakni area pembuluh darah besar dan jantung. Penyembelihan dilakukan dengan cepat untuk meminimalkan rasa nyeri dan stres (Chulayo et al., 2012). Metode penyembelihan dapat dilakukan dengan cara pemingsanan (stunning) dan tanpa pemingsanan (non-stunning). Stunning bertujuan untuk memingsankan hewan sebelum penyembelihan (Zivotofsky dan Strous, 2012). Stunning dilakukan untuk memudahkan imobilisasi hewan yang disembelih (Bergeaud-Blackler, 2007), menjamin keamanan petugas pemotongan hewan (Fikri dan Purnama, 2020), meminimalkan rasa nyeri, rasa takut dan stres pada hewan selama proses penyembelihan (Hindle et al., 2010), dan dapat memengaruhi kualitas daging (Fikri et al., 2017).

Menurut OIE (2011) stunning dapat dilakukan dengan metode elektrik, mekanis maupun menggunakan gas. Stunning secara elektris dilakukan dengan alat penjepit yang dialirkan listrik di kepala atau tubuh hewan, secara mekanis dilakukan dengan menggunakan captive bolt stun gun sedangkan stunning dengan gas dilakukan menggunakan paparan gas dengan kadar $80-90 \%$ selama tiga menit (EFSA, 2006). Hewan yang biasa disembelih dengan metode stunning salah satunya adalah babi. Stunning secara mekanis pada babi, selain menggunakan captive bolt stun gun juga dilakukan dengan memukul tepat daerah prefrontal (Goba, 2013).

Stunning merupakan isu animal welfare yang sering diperdebatkan (Farouk et al., 2014). Hewan yang disembelih tanpa stunning dapat merasakan nyeri dan menderita selama belum benar-benar hilang kesadaran, sehingga stunning dianggap sebagai metode penyembelihan yang lebih sesuai dengan animal welfare (Kim et al., 2013). Menurut Adzitey (2011) stunning dapat mengakibatkan stres apabila operator (stunner) kurang terlatih atau alat stunning yang berfungsi kurang baik.

Menurut Bourguet et al. (2011) dan Sabow et al. (2015) metode penyembelihan memegang peran penting dalam menentukan kualitas daging dan dapat memengaruhi metabolisme otot post mortem. Metode penyembelihan yang kurang baik menyebabkan stres sebelum pemotongan (pre-slaughter stress). Preslaughter stress merupakan salah satu faktor yang memengaruhi kualitas daging berupa Dark Firm Dry (DFD) (Channon et al., 2000) maupun Pale Soft Oxydative (PSE) (Rosenvolt dan Andersen, 2003). Superoxide dismutase (SOD) menjadi salah satu biomarker yang digunakan untuk mengetahui stres hewan (Del Rio, 2005). Aktivitas SOD berperan penting dalam adaptasi tubuh terhadap stres melalui penghambatan Reactive Oxygen Spesies (ROS) (Surai, 2016). Penelitian ini bertujuan untuk menentukan pengaruh electrical stunning terhadap aktivitas SOD serum sebagai indikator pre-slaughter stress pada babi Landrace.

\section{METODE PENELITIAN}

Penelitian dilakukan di peternakan dan rumah pemotongan babi Patoman, Banyuwangi. Prosedur handling dan restraint untuk babi yang disembelih dengan stunning dan nonstunning selama penelitian sesuai dengan diagram alir Standard Operasional Prosedur (SOP). Ijin penelitian didapat dari Badan Kesatuan Bangsa dan Politik Kabupaten Banyuwangi.

\section{Perlakuan Babi}

Penelitian eksperimental dilakukan dengan rancangan pre-post test group design. Babi dipilih secara acak sesuai dengan kriteria, yakni babi jantan dewasa yang telah dikebiri, breed Landrace, dan bobot badan $115 \pm 20 \mathrm{~kg}$.

Sejumlah 18 ekor babi dibagi menjadi dua kelompok, yakni sembilan ekor kelompok dengan stunning dan sembilan ekor kelompok -nonstunning. Metode penyembelihan dilakukan dengan electrical stunning dan non-stunning. Electrical stunning merupakan metode dengan mengaliri listrik pada dua elektroda yang dipasang di kepala hewan. Menurut Pleiter (2010) bahwa standard yang digunakan untuk electrical stunning pada babi berusia lebih dari enam minggu adalah 220 volt dan 1,3 ampere. Menurut Goba (2013) metode penyembelihan non-stunning dilakukan tanpa pemingsanan pada babi. Cara penyembelihan dengan menusuk bagian leher ke arah anterior sternum menuju area pembuluh darah besar dan jantung. 
Pengambilan Serum dan Pengujian SOD

Sebanyak $3 \mathrm{~mL}$ darah pre treatment diambil melalui Vena auricular sedangkan post treatment diambil melalui Vena jugularis atau pancaran pertama setelah leher babi ditusuk. Vacutainer plain $5 \mathrm{~mL}$ digunakan dan diberi label dengan keterangan perlakuan dan kode pemotongan babi. Serum didapatkan dengan menaruh sampel darah pada suhu ruang selama 1-2 jam kemudian disentrifus dengan kecepatan 6.000 rpm selama 15 menit menggunakan sentrifugator (EBA $20^{\circledR}$, Hettich, Massachusetts, USA). Serum adalah lapisan jernih berwarna kuning muda yang berada di bagian atas tabung (Putra et al., 2012). Serum kemudian dipindahkan ke dalam microtube menggunakan micropipette dan yellow tip, dan disimpan pada suhu $4^{\circ} \mathrm{C}$ di dalam cool box yang berisi ice gell untuk menunggu pengukuran aktivitas SOD.

Pengukuran SOD dilakukan dengan kit (StressXpress ${ }^{\circledR}$ SOD Activity Kit, Elabscience, Texas, USA). Menurut StressMarq Bioscience Inc. (2019), langkah pengujian aktivitas SOD diawali dengan membuat larutan standard sebanyak enam tabung. Sebanyak $250 \mu \mathrm{L}$ enzim SOD digunakan sebagai larutan stock dengan aktivitas SOD 4 U/mL. Pengenceran larutan standard selanjutnya adalah dilakukan dengan menambahkan Buffer Assay sebanyak $75 \mu \mathrm{L}$ hingga didapat larutan standard dengan aktivitas SOD $2 \mathrm{U} / \mathrm{mL}, 1 \mathrm{U} / \mathrm{mL}, 0,5 \mathrm{U} / \mathrm{mL}, 0,25$ $\mathrm{U} / \mathrm{mL}, 0,125 \mathrm{U} / \mathrm{mL}$ dan $0,0625 \mathrm{U} / \mathrm{mL}$. Persiapan reagen meliputi pembuatan Xanthine Oxidase dan Substrat.

Serum hasil koleksi sampel dan setiap konsentrasi larutan standard SOD dipindahkan sebanyak $10 \mu \mathrm{L}$ ke dalam microplate dengan 96 sumuran/well. Pindahkan pula $10 \mu \mathrm{L}$ Buffer Assay sebagai Zero Standard. Setiap sumuran ditambahkan $50 \mu \mathrm{L}$ substrat dan $25 \mu \mathrm{L}$ Xanthine Oxidase, lalu diinkubasi pada suhu ruang selama 20 menit. Microplate kemudian dibaca dengan metode kolorimetri yakni intensitas warna yang direpresentasikan dengan nilai optical density (OD) sepanjang ë $=430 \mathrm{~nm}$ menggunakan spectrophotometer. Nilai OD yang didapat dihitung dengan rumus berikut. Nilai penghambatan $=[(\mathrm{OD}$ sampel $\mathrm{x}(\mathrm{OD}$ zero standar $\left.^{-1}\right] \times 100 \%$, sedangkan Aktivitas SOD= Nilai penghambatan $\mathrm{x}$ Faktor pengenceran.

\section{Analisis Data}

Hasil aktivitas SOD direpresentasikan sebagai rataan \pm simpangan baku (mean \pm standard deviasi) kemudian dianalisis dengan uji T berpasangan untuk membandingkan aktivitas SOD serum antara stunning dan nonstunning pada fase pre dan post treatment. Analisis data dilakukan dengan program SPSS v23 for Windows (IBM, USA).

\section{HASIL DAN PEMBAHASAN}

Evaluasi hasil selama fase post treatment pada babi yang mendapat stunning dan nonstunning menunjukkan peningkatan SOD masing-masing $152,25 \pm 25,17$ dan $278,29 \pm 87,61$ dibandingkan fase pre treatment masing-masing $96,13 \pm 48,35$ dan $140,45 \pm 77,79$ (Gambar 1). Namun, hasil stunning $(56,12 \pm 54,47)$ menunjukkan penurunan SOD secara signifikan $(\mathrm{p}<0,05)$ dibandingkan non-stunning $(13784 \pm 66,63)$ (Gambar 2).

Stunning menjadi titik kritis yang tidak hanya berpengaruh terhadap aspek animal walfare, tetapi juga dapat memengaruhi kualitas daging (Warner et al., 2010). Stunning bertujuan meminimalkan rasa nyeri selama proses penyembelihan (Gregory, 2007) dan memudahkan imobilisasi hewan sehingga proses penyembelihan menjadi lebih mudah dan aman (Sabow et al., 2018). Stres akibat rasa nyeri selama proses penyembelihan dapat diklasifikasikan sebagai paparan stres akut. Stres akut ditandai peningkatan produksi ROS diikuti aktivitas SOD. Tingkat stres babi Landrace yang disembelih dengan metode electrical stunning dan non-stunning dapat diketahui dengan membandingkan aktivitas SOD serum (Hu et al., 2019).

Electrical stunning dilakukan dengan memasangkan dua elektroda di antara mata dan pangkal telinga, dilakukan ketika posisi babi berdiri tanpa handling dan restrain dengan interval waktu 3-5 detik. Penyembelihan dilakukan ketika hewan memasuki fase klonik ditandai seluruh otot tubuh penderita berkontraksi dan bergerak secara ritmis dan kehilangan kesadaran dari lingkungan sekitar (Velarde et al., 2001). Non-stunning dilakukan dengan memasukkan babi ke kandang besi kemudian diikat bagian rahangnya dan ditarik ke belakang hingga tubuh babi berhimpitan dengan kandang besi. Metode penyembelihan pada kedua kelompok dilakukan dengan cara yang sama yakni dengan menusuk area leher menuju ke arah jantung (Velarde et al., 2000). Hasil analisis uji korelasi kadar SOD pada perlakuan pre dan post stunning menunjukkan 


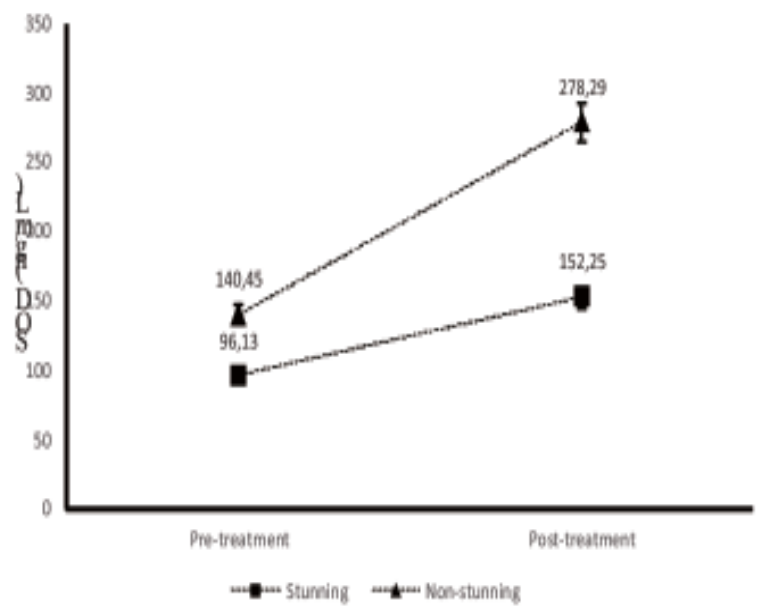

Gambar 1. Aktivitas superoxide dismutase (SOD)babi pada pre dan post treatment dengan masing masing perlakuan stunning dan -nonstunning

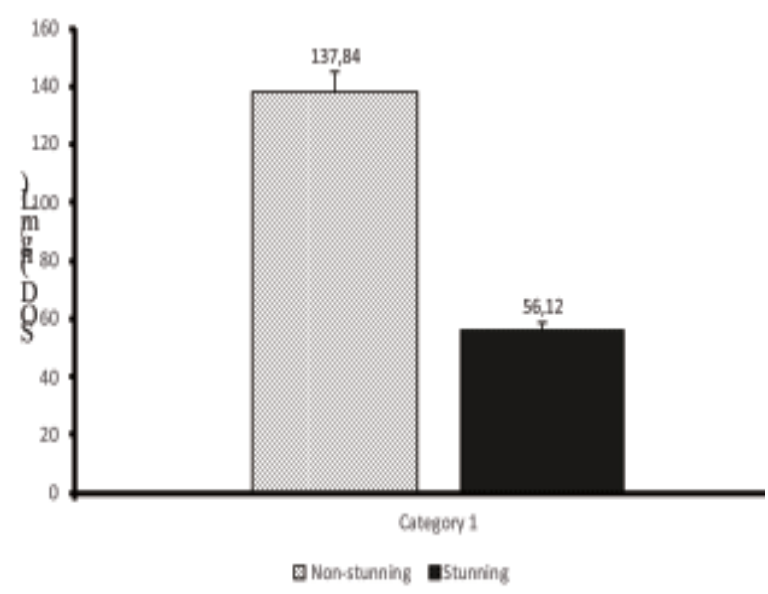

Gambar 2. Perbandingan penurunan superoxide dismutase (SOD) babi stunning dan -nonstunning

adanya linearitas yang tidak signifikan dengan persamaan $\mathrm{y}=0,001 \mathrm{x}+152,15$. Kadar SOD kelompok pre dan post non-stunning terdapat linearitas dengan persamaan $\mathrm{y}=0,7673 \mathrm{x}+$ 170,52 (Gambar 3). Kelompok yang diberi electrical stunning dapat dikatakan memiliki tingkat stres yang stabil dibandingkan yang disembelih dengan non-stunning.

Babi Landrace tidak merasakan nyeri selama proses penyembelihan setelah penggunaan electrical stunning. Kehilangan rasa nyeri pada penyembelihan electrical stunning terjadi akibat arus listrik yang melalui (a)

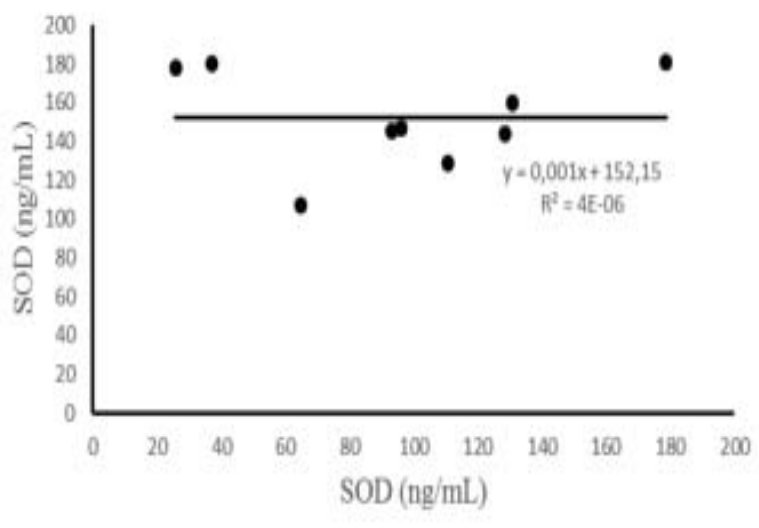

(b)

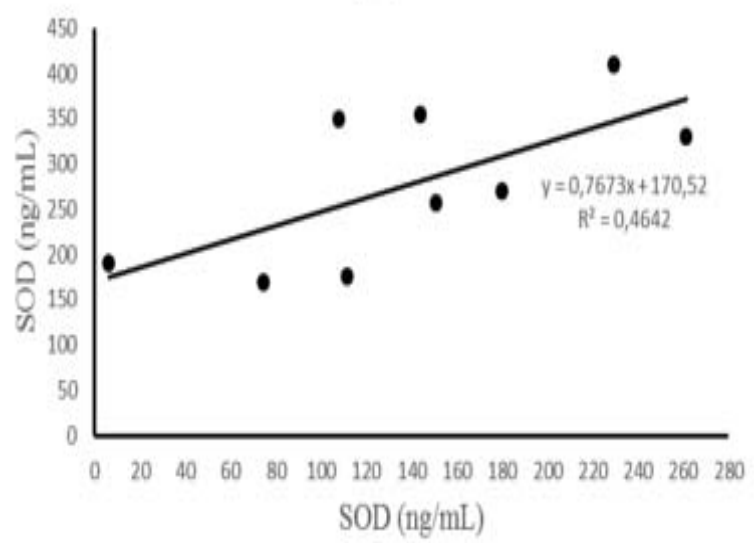

Gambar 3. Korelasi kadar superoxide dismutase (SOD) pre terhadap post treatment pada (a) babi yang mendapat stunning dan (b) babi yang nonstunning

otak dan menyebabkan gangguan aktivitas otak, sehingga hewan kehilangan kesadaran dan tidak peka terhadap rasa nyeri. Electrical stunning menyebabkan hewan mengalami grand mal epileptic atau kejang tonik-klonik yang terjadi dalam tiga fase yakni tonik, klonik dan recovery (HSA, 2016). Menurut Guyton dan Hall (2016), rasa nyeri merupakan salah satu jenis rangsangan yang menyebabkan hewan mengalami stres. Stres yang dialami hewan memicu respons hypothalamus-pituitaryadrenal (HPA) Axis yang merangsang sekresi hormon kortisol. Hormon kortisol bekerja menstimulasi terjadinya glukoneogenesis pada hepar, meningkatkan mobilisasi asam amino dari jaringan ekstrahepatik dan lipolisis pada jaringan adiposa yang menghasilkan gliserol dan asam lemak. Asam amino dan gliserol akan dibawa ke hepar untuk proses glukoneogenesis, 
sedangkan asam lemak akan dioksidasi menjadi energi melalui jalur oksidasi â asam lemak.

Stres juga menstimulasi kerja saraf simpatis sehingga menyebabkan medulla adrenal mensekresikan hormon adrenalin dan noradrenalin (Carrol et al., 2017). Hormon adrenalin akan bekerja meningkatkan terjadinya glikogenolisis di hati dan otot, serta meningkatkan pelepasan glukosa ke dalam darah (Guyton dan Hall, 2016). Proses glukoneogenesis dan glikogenolisis menyebabkan hiperglikemia sehingga terjadi mekanisme autooksidasi glukosa, glikasi dan pembentukan dikarbonil yang berakibat pada peningkatan produksi ROS (Fakhruddin et al., 2017). Tubuh memiliki sistem pertahanan terhadap ROS berupa antioksidan endogen yakni SOD. Enzim SOD merupakan pertahanan terdepan dalam menghadapi kerusakan sel akibat ROS dengan mengkatalis perubahan radikal $\mathrm{O}_{2}^{-}$menjadi molekul $\mathrm{O}_{2}$ dan $\mathrm{H}_{2} \mathrm{O}_{2}$ (Vaziri et al., 2003). Enzim SOD pada mamalia dapat dibedakan menjadi SOD1 (cytoplasmic $\mathrm{Cu}$ / ZnSOD), SOD2 (mitocondrial MnSOD) dan SOD3 (extracellular Cu/ZnSOD) dengan lokasi berbeda. Enzim SOD1 dan SOD2 terdapat di dalam sel, sedangkan SOD3 terdapat pada exstrasellular matrix, permukaan sel, cairan ekstraselluler dan plasma darah (Fukai dan Ushio-Fukai, 2011).

Menurut $\mathrm{Yu}$ et al. (2011), serum mengandung zat metabolit dan memberikan nilai sensitivitas yang lebih tinggi dibanding plasma, sehingga serum dianggap lebih potensial digunakan sebagai sampel pengujian dibanding plasma. Pengujian aktivitas SOD dilakukan dengan mereaksikan xanthine dengan xanthine oxidase sehingga terbentuk radikal dan mengubah substrat menjadi berwarna kuning. Enzim SOD dalam sampel akan mendegradasi radikal dan memengaruhi kepekatan warna kuning yang terbentuk (StressMarq Bioscience Inc., 2019). Aktivitas SOD yang tinggi di dalam sampel serum pada penelitian ini ditandai dengan terbentuknya warna kuning pucat sehingga menghasilkan nilai absorbansi yang lebih tinggi, sedangkan aktivitas SOD yang rendah di dalam sampel serum akan ditandai dengan terbentuknya warna kuning pekat sehingga akan menghasilkan nilai absorbansi yang lebih rendah. Perbedaan respons individu terhadap paparan stres disebabkan oleh faktor genetik dan perbedaan kemampuan adaptasi sehingga menyebabkan perbedaan respons sekresi hormon kortisol (Purnama et al., 2019).

\section{SIMPULAN}

Hasil penelitian menunjukkan terjadinya penurunan aktivitas SOD pada serum babi Landrace yang disembelih dengan electrical stunning dan electrical stunning juga dapat menstabilkan kadar SOD pre dan post treatment.

\section{SARAN}

Penelitian stunning pada babi dapat dilakukan lebih lanjut untuk mengetahui kadar MDA, GPx serta korelasinya dengan berat badan dan faktor lain yang memicu stress. Penelitian diharapkan dapat menjadi acuan metode penyembelihan terbaik sesuai prinsip animal welfare dan mempertahankan kualitas daging hewan.

\section{UCAPAN TERIMA KASIH}

Peneliti mengucapkan terima kasih kepada Lembaga Penelitian dan Inovasi Universitas Airlangga, Fakultas Kedokteran Hewan Universitas Airlangga dan Dinas Pertanian Kabupaten Banyuwangi atas dukungan dan fasilitas selama penelitian.

\section{DAFTAR PUSTAKA}

Adzitey F. 2011. Mini Review: Effect of PreSlaughter Animal Handling on Carcass and Meat Quality. Int Food Res J 18(2): 485491.

Bergeaud-Blackler F. 2007. New Challenges for Islamic Ritual Slaughtering: A European Perspective (Forthcoming). J Ethnic Migration Stud 33(6): 965-980.

Bourguet C, Deiss V, Tannugi CC, Terlouw EMC. 2011. Behavioural and Physiological Reactions of Cattle in A Commercial Abattoir: Relationships With Organisational Aspects Of The Abattoir And Animal Characteristics. Meat Sci 88(1): 158-168. 
Carrol TB, Aron DC, Findling JW, Tyrell JB. 2017. Glucocorticoids and Adrenal Androgens. In: Greenspan FS, Gardner DG Basic and Clinical Endocrinology $10^{\text {th }} \mathrm{ed}$. San Fransisco: USA. Lange Medical Book. Hlm. 299-308.

Channon HA, Payne AM, Warner RD. 2000. Halothane Genotype, Pre-Slaughter Handling and Stunning Methods All Influence Pork Quality. Meat Sci 56: 291299.

Chulayo AY, Tada O, Muchenje V. 2012. Research on Preslaughter Stress and Meat Quality: A Review of Challenges Faced Under Practical Conditions. App Anim Husbandry Rural Dev 5: 1-6.

Dannar NN, Pisestyani H, Santoso K. 2015. Waktu Henti Darah Memancar pada Penyembelihan Sapi dengan Pemingsanan dan Tanpa Pemingsanan. Bogor. Fakultas Kedokteran Hewan. Institut Pertanian Bogor. Hlm. 3. https://docplayer.info/ 144609080

Del Rio D, Steward AJ, Pellegrini N. 2005. A Review of Recent Studies on Malondialdehyde as Toxic Molecule and Biological Marker of Oxidative Stress. $J$ Nutr Met Cardio Dis 15(4): 316-328.

[EFSA] European Food Safety Authority. 2006. The Welfare Aspects Of The Main Systems Of Stunning And Killing Applied To Commercially Farmed Deer, Goats, Rabbits, Ostriches, Ducks, Geese, And Quail. EFSA J 326: 1-18.

Fakhruddin S, Alanazi W, Jackson KE. 2017. Diabetes-Induced Reactive Oxygen Species: Mechanism of Their Generation and Role in Renal Injury. J Diabetes Research 1: 131.

Farouk M, Al-Mazeedi H, Sabow A, Bekhit A, Adeyemi K, Sazili A, Ghani A. 2014. Halal and Kosher Slaughter Methods and Meat Quality: A Review. Meat Sci 98(3): 505519.

Fikri F, Hamid IS, Purnama MTE. 2017. Uji organoleptis, $\mathrm{pH}$, uji eber dan cemaran bakteri pada karkas yang diisolasi dari kios di Banyuwangi. J Med Vet 1(1): 23-27.

Fikri F, Purnama MTE. 2020. Biosecurity Application of Small Scale Chicken Abattoir in Sidoarjo, East Java, Indonesia. Sys Rev Pharm 11(6): 226-229.

Fukai T, Ushio-Fukai M. 2011. Superoxide Dismutases: Role in Redox Signaling, Vascular Function, and Diseases. Antioxidants Redox Sign 15(6): 1583-1606.

Goba MA, Nuraini H, Cyrilla L. 2013. Penanganan dan Distribusi Karkas dan Non Karkas dari Tempat Pemotongan Babi Jeletreng Gunung Sindur Bogor. Bogor. Fakultas Peternakan. Institut Pertanian Bogor. Hlm. 10-11. https://repository.ipb. ac.id/handle/123456789/66204

Gregory NG. 2007. Chapter 12: Meat Quality. In: 'Animal Welfare And Meat Production'. $2^{\text {nd }}$ edn. Wallingford. United Kingdom. CABI Publishing. Hlm. 213-226.

Guyton AC, Hall JE. 2016. Textbook of Medical Physiology. Ed. 13. Elsevier. Mississippi: USA. Hlm. 780-862.

Hindle VA, Lamboij E, Reimert GM, Workel RD, Gerritzen MA. 2010. Animal Welfare Concerns During The Use Of The Water Bath For Stunning Broiler, Hens, Ducks. Poultry Sci J 89(3): 401-412.

[HSA] Humane Slaughter Association. 2016. Electrical Stunning of Red Meat Animal. https://www.hsa.urg.uk. [13 April 2019]

Hu R, He Y, Arowolo MA, Wu S, He J. 2019. Polyphenols as Potential Attenuator of Heat Stress in Poultry Production. J Antioxidants 8(67): 3-11.

Kim GD, Lee HS, Jung EY, Lim HJ, Seo HW, Lee YH, Jang SH, Baek SB, Joo ST, Yang HS. 2013. The Effects of Gas Stunning on Meat Quality of Cattle Compared with Captive Bolt Stunning. Livestock Sci 157(1): 312-316.

[OIE] Office International des Epizooties. 2011. Slaughter of Animals. Chapter 7.5. Paris (FR): Terrestrial Animal Health Code World Organisation for Animal Health. Hlm. 332355.

Pleiter H. 2010. Review of Stunning and Halal Slaughter. Meat and Livestock Australia (MLA). Sydney. Australia. Hlm. 12-20.

Purnama MTE, Dewi WK, Prayoga SF, Triana NM, Aji BSP, Fikri F, Hamid IS. 2019. Preslaughter Stress in Banyuwangi Cattle 
During Transport. Indian Vet J 96(12): 50 52.

Putra GA, Hidayat EM, Thadeus MS. 2012. Dampak Penundaan Pemisahan Serum dari Sel Darah Terhadap Hasil Pemeriksaan Kadar Glukosa Darah dengan Metode Heksokinase. Bina Widya 23(5): 264-270.

Rosenvolt K, Andersen HJ. 2003. Factors Of Significance For Pork Quality-A Review. Meat Sci 64: 219-237.

Sabow AB, Sazili AQ, Zulkifli I, Goh YM, Ab Kadir MZA, Abdulla NR, Nakyinsige K, Kaka U, Adeyemi KD. 2015. A Comparison of Bleeding Efficiency, Microbiological Quality and Lipid Oxidation in Goats Subjected to Conscious Halal Slaughter and Slaughter Following Minimal Anaesthesia. Meat Sci 104: 78-84.

Sabow AB, Goh YM, Zulkifli I, Ab Kadir MZ, Kaka U, Adeyemi KD, Abubakar AA, Imlan JC, Ebrahimi M, Sazili AQ. 2018. Electroencephalographic and Blood Parameters Changes in Anaesthetised Goats Subjected To Slaughter Without Stunning And Slaughter Following Different Electrical Stunning Methods. Anim Prod Sci 59(5): 849-860.

StressMarq Bioscience Inc. 2019. StressXpress $₫$ SOD Activity Kit Quantitative Colorimetric Measurement of Superoxide Dismutase Activity Catalog SKT-214. https:// www.stressmarq.com/products/assay-kits/ sod-activity-kit-skt-214/. pp.1-20

Surai PF. 2016. Antioxidant Systems in Poultry Biology: Superoxide Dismutase. J Anim Res Nutr 1(8): 1-17.
Vaziri ND, Michael D, Nathan DH, Boroujerdirad L, Sindhu RK. 2003. Oxidative Stress and Dysregulation of Superoxide Dismutase and NADPH Oxidase in Renal Insufficiency. Kidney Int 63: 179-185.

Velarde A, Gisperta M, Faucitanoa L, Mantecab X, Diestre A. 2000. The Efect of Stunning Method on The Incidence of PSE Meat and Haemorrhages in Pork Carcasses. Meat Sci 55: 309-314.

Velarde A, Gispert M, Faucitano L, Alonso P, Manteca X, Diestre A. 2001. Effects of The Stunning Procedure and The Halothane Genotype on Meat Quality and Incidence of Haemorrhages in Pigs. Meat Sci 58(3): 313319.

Warner RD, Greenwood PL, Pethick DW, Ferguson DM. 2010. Genetic and Environmental Effects on Meat Quality. Meat Sci 86(1): 171-183.

Yu Z, Kastenmuller G, He Y, Belcredi P, Moller G, Prehn C, Mendes J, Wahi S, RoemischMargi W, Ceglerek U, Polonikov A, Dahmen N, Prokisch H, Xie L, Li Y, Wichmannn HE, Peters A, Kronenberg F, Suhre K, Adamski J, Illig T, Wang-Sattler R. 2011. Differences between Human Plasma and Serum Metabolite Profiles. Ploss One 6(7): 1-6.

Zivotofsky AZ, Strous RD. 2012. A Perspective On The Electrical Stunning Of Animals: Are There Lessons to be Learned From Human Electro Convulsive Therapy (ECT). Meat Sci 90(4): 956-961. 